\title{
Mechanisms of insulin resistance in obesity
}

\author{
Jianping Ye \\ Antioxidant and Gene Regulation Laboratory, Pennington Biomedical Research Center, Louisiana \\ State University System, Baton Rouge, LA70808, USA
}

\begin{abstract}
Obesity increases the risk for type 2 diabetes through induction of insulin resistance. Treatment of type 2 diabetes has been limited by little translational knowledge of insulin resistance although there have been several well-documented hypotheses for insulin resistance. In those hypotheses, inflammation, mitochondrial dysfunction, hyperinsulinemia and lipotoxicity have been the major concepts and have received a lot of attention. Oxidative stress, endoplasmic reticulum (ER) stress, genetic background, aging, fatty liver, hypoxia and lipodystrophy are active subjects in the study of these concepts. However, none of those concepts or views has led to an effective therapy for type 2 diabetes. The reason is that there has been no consensus for a unifying mechanism of insulin resistance. In this review article, literature is critically analyzed and reinterpreted for a new energy-based concept of insulin resistance, in which insulin resistance is a result of energy surplus in cells. The energy surplus signal is mediated by ATP and sensed by adenosine monophosphateactivated protein kinase (AMPK) signaling pathway. Decreasing ATP level by suppression of production or stimulation of utilization is a promising approach in the treatment of insulin resistance. In support, many of existing insulin sensitizing medicines inhibit ATP production in mitochondria. The effective therapies such as weight loss, exercise, and caloric restriction all reduce ATP in insulin sensitive cells. This new concept provides a unifying cellular and molecular mechanism of insulin resistance in obesity, which may apply to insulin resistance in aging and lipodystrophy.
\end{abstract}

\section{Keywords}

type 2 diabetes; energy expenditure; inflammation; lipotoxicity; mitochondria; hyperinsulinemia; adenosine monophosphate-activated protein kinase (AMPK)

\section{Introduction}

Insulin reduces blood glucose by inducing glucose uptake in insulin-sensitive tissue such as skeletal muscle, fat and heart. Insulin also inhibits glucose production in liver, kidney and small intestine in the control of blood glucose. Insulin resistance occurs when the insulinsensitive tissue loss response to insulin. In the insulin sensitivity assays, insulin resistance has following characteristics: hyperinsulinemia and hyperglycemia in fasting condition, increased glycosylated haemoglobin (HbA1c), postprandial hyperglycemia, hyperlipidemia, impaired glucose tolerance, impaired insulin tolerance, decreased glucose infusion rate, increased hepatic glucose production, loss of first phase secretion of insulin, hypoadiponectinemia, and increased inflammatory markers in plasma. 
Insulin has many physiological activities in which reducing blood glucose is a primary function. In addition, insulin stimulates synthesis of fatty acids and glycogen, promotes mitochondrial function, improves microcirculation and induces cell proliferation [1,2]. Insulin resistance is a condition whereby insulin-induced glucose uptake is impaired in the insulin-sensitive tissue. The failure is a result of inhibition of the insulin signaling pathway. It is believed that insulin resistance leads to hyperinsulinemia when $\beta$-islets produce a large amount of insulin in an effort to control of blood glucose. In contrast to type 1 diabetes that exhibits hyperglycemia and hypoinsulinemia, type 2 diabetes often exhibit hyperglycemia and hyperinsulinemia. Insulin resistance is the primary cause of type 2 diabetes and it occurs many years before type 2 diabetes starts in human. Several factors have been proposed to explain the mechanisms of insulin resistance. These include: (a) obesity; (b) inflammation; (c) mitochondrial dysfunction; (d) hyperinsulinemia; (e) lipotoxicity/hyperlipidemia; (f) genetic background; (g) endoplasmic reticulum (ER) stress; (h) aging; (i) oxidative stress; (j) fatty liver; (k) hypoxia; (l) lipodystrophy; (m) pregnancy. Many of these factors are associated with obesity and aging, which are the major risk factors for insulin resistance in the general population. Here, obesity-associated factors will be discussed in detail with a focus on inflammation, mitochondrial dysfunction, and hyperinsulinemia. In addition, aging, gene background, hyperlipidemia, ER stress, oxidative stress, hypoxia and pregnancy will be discussed for their possible roles in the pathogenesis of insulin resistance. Both supporting and conflicting evidence will be reviewed for each hypothesis or concept.

\section{Inflammation and insulin resistance}

In obesity, there is a chronic and low grade inflammation that is involved in the pathogenesis of several chronic diseases, such as type 2 diabetes, hypertension, atherosclerosis, fatty liver, cancer, asthma, and sleep apnea. Inflammation is a physiological process characterized by elevated number of white blood cells or increased levels of proinflammatory cytokines in the circulation or tissue. In general, inflammation is required for organ remodeling, tissue repairing, wound healing and immunity against infections. Inflammation is a protective reaction in the body to control the harmful insults and to initiate the healing process. Over reaction of inflammatory response usually leads to multiple side effects such as tissue injury and organ dysfunction. Obesity-associated inflammation starts in adipose tissue and liver with elevated macrophage infiltration and expression of proinflammatory cytokines. The pro-inflammatory cytokines enter the blood stream to cause systemic inflammation. In obesity, inflammation has both beneficial and detrimental effects [3].

The history of obesity-associated inflammation is more than 100 years with the first observation that blood glucose was reduced by the anti-inflammation drug aspirin in type 2 diabetic patients a century ago [4]. Fifty years ago, fibrinogen was reported to be elevated in the circulation of obese patients. In 1993, an increase in pro-inflammatory cytokine, TNF-a, was found in the adipose tissue of obese mice in association with insulin resistance [5], which opens the current page in the study of obesity-associated inflammation. Then, Creactive protein (CRP), interleukin 6 (IL-6), plasminogen activator inhibitor-1 (PAI-1) and many other inflammation mediators were found in the plasma of obese patients or animals in the last decade [6,7]. In addition, activities of signaling molecules in the inflammatory pathways such as I $\kappa \mathrm{B} a$ kinase $\beta$ (IKK $\beta$ ) and c-Jun N-terminal kinase 1 (JNK1) were found to be activated in adipose tissue and liver $[8,9]$. Those intracellular signaling pathways are activated in obesity by TNF-a, free fatty acids, diaglyceride (DAG), ceramide, ROS and hypoxia [10]. TNF-a acts through its p55 receptor to inhibit IRS-1 in the insulin signaling pathway [11]. Activation of IKK $\beta$ and JNK1 involves in IRS-1 inhibition by TNF-a $[8,12,13]$. In addition, TNF- $a$ also inhibits PPAR $\gamma$ function in the induction of insulin resistance in adipose tissue $[14,15]$. 
The IKK $\beta / \mathrm{NF}-\kappa \mathrm{B}$ pathway is a dominant inflammation signaling pathway that is extensively studied in cancer and immunology fields. The serine kinase IKK has three major isoforms including IKKa (IKK1), IKK $\beta$ (IKK2) and IKK $\gamma$, which form an enzyme complex in the cytosol [16]. Of the three IKK isoforms, IKK $\beta$ catalyzes I $\kappa B$ a phosphorylation, which makes the IKBa protein ubiquitination and then degradation in proteasome. As a result, NF$\kappa \mathrm{B}$ translocates from cytoplasm into nucleus to induce gene expression. IKK $\beta$ is able to inhibit insulin signaling by phosphorylation of IRS-1 at multiple serine residues including Ser307 and Ser270 in adipocytes $[12,17]$.

In the JNK-AP1 pathway, JNK (c-JUN N-terminal kinase), a ubiquitous serine kinase, is extensively studied in cancer for carcinogenesis and apoptosis. The activity of JNK was first found in the pathogenesis of insulin resistance for phosphorylation of IRS-1 S307 (S312 in human), which inhibits the insulin signaling pathway in response to TNF-a signal [13,18]. JNK has several isoforms including JNK1, JNK2, and JNK3. JNK regulates gene expression through activation of transcription factor AP-1. In the JAK/STAT pathway, STAT (signal transducer and activator of transcription) is a latent transcription factor in the cytoplasm and the activation requires tyrosine phosphorylation by JAK kinases, which induces dimerization and translocation of STAT to the nucleus. STAT3 is closely related to obesity as it is activated by IL-6, leptin, and IL-10. The pathway regulates metabolism through central and peripheral mechanisms.

Inflammation inhibits the insulin signaling activity in adipocytes and hepatocytes through several mechanisms. The first is inhibition of IRS-1 (insulin receptor substrate 1) and insulin receptor in the insulin signaling pathway $[19,20]$. IRS-1 receives signals from insulin receptor in the insulin signaling pathway. The second is inhibition of PPAR $\gamma$ function $[15,20]$. PPAR $\gamma$ is a nuclear receptor that drives lipid synthesis and fat storage in cells. Its activity is dependent on ligands, which include long chain fatty acids and thiazolidinedione (TZD). It induces expression of enzymes or proteins in lipogenesis or storage through transcriptional activation. Reduction of PPAR $\gamma$ activity contributes to insulin resistance. The third is to increase plasma free fatty acid (FFA) through stimulation of lipolysis and blocking TG synthesis [1]. The three pathways mediate these effects of inflammation. These effects are primarily observed in adipose tissue and liver. Muscle insulin action is not sensitive to inflammation.

In obesity, several alterations contribute to the initiation of chronic inflammation, such as ER stress, adiponectin reduction, leptin elevation, adipocytes death, macrophage infiltration and lipolysis [3]. Adipose tissue hypoxia has been proposed as a common root for all of these changes [10]. Hypoxia may directly or indirectly induce expression of proinflammatory cytokines in fat. Elevation of pro-inflammatory cytokines in fat and circulation has been documented in obesity in other reviews [6,7]. The representative cytokines include TNF-a, IL-1, IL-6, MCP-1 and PAI-1. Cytokine was originally used as a term for a secreted protein that mediates signals among immune cells (T cells, B cells and macrophages) by interaction with a specific cell membrane receptor. They are different from hormones since they mainly act in the paracrine manner to regulate cell proliferation, differentiation and metabolism. It is hard to separate cytokine from hormone in many cases, such as leptin and adiponectin. Cytokine that is predominantly produced by adipocytes is called "adipokines." Functions of pro-inflammatory cytokines are complex in obesity including inhibition of adipocytes [21-23], stimulation of angiogenesis, fuel mobilization, induction of energy expenditure [24-28] and suppression of food intake [26,29]. These activities are required in the control of energy balance in the body.

Macrophage infiltration is enhanced in the adipose tissue in obesity [30-33]. Macrophage is derived from monocyte and controls local inflammatory responses in tissue. Adipose tissue 
macrophage (ATM) is much more active than adipocytes in the production of TNF-a and other pro-inflammatory cytokines [30-33]. Inhibition of macrophage by TZDs was found to enhance insulin sensitivity [34,35]. Macrophage infiltration is regulated by chemokines and debris of dead cells. ATM is divided into two types, M1 and M2. An increase in M1 and decrease in M2 were found in adipose tissue of obese mice [34,36]. M1 promotes inflammation and M2 inhibits inflammation in general [37,38]. M1 macrophages express a high level of interleukin 12 (IL-12), inducible nitric oxide synthase (iNOS or NOS2), and major histocompatibility complex (MHC) class II expression [37,38]. M1 has low level of arginase and IL-10. M2 macrophages have an anti-inflammatory and angiogenic phenotypes. M2 macrophages develop in response to IL-4 and IL-13. M2 macrophages express lower levels of IL-12, iNOS and MHC class II. M2 macrophages produce a high level of anti-inflammatory cytokine IL-10, and arginase that depletes NO donor arginine. TZD reduces $M 1$ and increase $M 2$ in obese mice [34], suggesting a role of M2 in the improvement of insulin sensitivity by TZD.

Emerging evidence suggests that macrophages have beneficial effects in adipose tissue. Macrophages are required for adipose tissue remodeling and adipogenesis. These activities of macrophages are found in adipose tissue growth in lean mice [39,40]. In addition, macrophages regulate vasculature and extracellular matrix remodeling through secretion of angiogenic factors $[41,42]$ and collagenase. They also regulate blood flow by production of vasodilator, such as NO. M1 macrophages produce a large amount of NO by expression of iNOS. Additionally, macrophages may serve to clean the cell debris of dead adipocytes in the adipose tissue [43].

In obesity, liver inflammation is associated with hepatic steatosis (fatty liver), a result of lipid accumulation in hepatocytes. Pro-inflammatory cytokines and Kupffer cell (liver macrophages) accumulation are elevated in the inflammatory response. Although these cytokines are known to block the insulin signaling pathway in hepatocytes, the biological significance of flammation remains to be the in investigated. Inflammation may also have beneficial effects in liver in terms of regulation of metabolism. Remodeling of extracellular matrix is required in the maintenance of hepatocyte function during liver expansion. IL-6 promotes hepatocyte proliferation that is required for hepatocyte regeneration to replace the injured hepatocytes [44].

Liver inflammation may be a feedback response in an effort to attenuate lipid accumulation in hepatocytes. One possibility is to enhance conversion of fatty acid into glucose in hepatic gluconeogenesis, in which fatty acid-derived acetyl-CoA is used as building materials in the production of glucose. The gluconeogenesis is normally inhibited by insulin and is enhanced under insulin resistance. Inflammation induces hepatic insulin resistance to promote gluconeogenesis. IKK $\beta$ overexpression in liver led to hepatic inflammation and hepatic insulin resistance [45]. IKK $\beta$ knockout in liver reduced inflammation and protected mice from insulin resistance [46]. In this way, inflammation protects liver from steatosis by stimulation of lipid utilization in hepatocytes. Gluconeogenesis is one approach to enhance lipid utilization. However, this possibility remains to be proved.

Though inflammation is well documented in the pathogenesis of insulin resistance in the literature, inflammation is not a good target in the treatment of insulin resistance [3]. This conclusion is supported by following facts: (a) Anti-inflammatory therapies failed to generate a satisfactory result in improving insulin sensitivity in most clinical trials although the hyperglycemia parameters were improved in some trials [3]; (b) Inflammation did not impair insulin sensitivity in multiple models of transgenic mice with chronic inflammation [27,47,48]; (c) Elevated plasma IL-6 (pro-inflammatory cytokine) is associated with improved insulin sensitivity in physical exercise [49]; (d) Pro-inflammatory cytokines 
induce energy expenditure and inhibit food intake in the study of cachexia [50], which favors insulin sensitivity; (e) Inflammation is an energy-consuming process in the body's defense against tissue injuries and pathogen infection [51]. Inflammation promotes negative energy balance. (f) Negative energy balance in the body has been known for long time to improve insulin sensitivity in the models of exercise, calorie restriction and weight loss [52,53]. Those classical and new studies have formed a challenge to the foundation of inflammatory theory.

\section{Mitochondrial dysfunction and insulin resistance}

Mitochondrial dysfunction is defined as reduction in mitochondrial number, density or function. As mitochondria is a primary subcellular organ for oxidation and metabolism of fatty acid and glucose, a reduction in mitochondrial function may contribute to FFA and lipid accumulation in favor of insulin resistance [54]. Although the hypothesis explains the association of improved mitochondrial function and insulin sensitivity in the models of physical exercise in humans and rodents [55], most exiting evidence suggests that mitochondrial dysfunction is a result of insulin resistance [56-58], instead of a cause of insulin resistance [59]. The evidence includes: (a) Insulin stimulates mitochondrial biogenesis [60,61]; (b) Mitochondrial number and function was not changed after improvement of insulin sensitivity from weight loss [59]; (c) Enhanced mitochondrial function in $\beta$-oxidation led to insulin resistance, and inhibition of $\beta$-oxidation with pharmacological inhibitors (etomoxir or oxfenicine) prevented the lipid-induced insulin resistance in rodents [57,58]; (d) Decreased mitochondrial function was associated with better insulin sensitivity and increased mitochondrial function induced insulin resistance in transgenic mice [57,58]; (e) In healthy human subjects, lipid infusion-induced insulin resistance was associated with enhanced mitochondrial $\beta$-oxidation [62,63]; (f) Insulin sensitizing agents (TZDs, metformin and berberine, etc.) all inhibited mitochondrial function of ATP production in cellular models [64-67]. Those lines of evidence support that mitochondria over activation in obesity may cause insulin resistance (Fig. 1). This is a strong argument about the role of mitochondrial dysfunction in the pathogenesis of insulin resistance.

\section{Hyperinsulinemia and insulin resistance}

Hyperinsulinemia means a constant high level of plasma insulin in the fasting condition. Although it is generally accepted that hyperinsulinemia is resulted from insulin resistance, studies also suggest that a high level of insulin may lead to insulin resistance, especially in the presence of fatty acid [1]. Insulin resistance is associated with hyper-insulinemia. It has been more than 30 years that insulin resistance is considered as a result of hyperinsulinemia, which represents a body's effort to prevent hyperglycemia. However, hyperinsulinemia also induces insulin resistance. The insulin signaling pathway has a negative feedback loop to control the pathway activity precisely in response to insulin stimulation [1]. This loop is activated by insulin signal to avoid activation insulin-induced stress responses [1]. This mechanism has received consistent support from human and animal studies $[1,68,69]$.

Hyperinsulinemia is derived from either over production or decreased clearance of insulin in obesity (Fig. 2). The balance of insulin production rate and insulin clearance rate determines plasma insulin level. $\beta$ cells in the pancreatic islets are the only source of insulin. In obesity, $\beta$ cells function is enhanced and the cell number is increased in the pancreatic islets during the weight gain [1,69]. These changes are related to the stimulation of $\beta$ cells by fatty acids/ glucose $[1,69]$. Leptin resistance in $\beta$ cells may contribute to over production of insulin by $\beta$ cells [70]. Leptin inhibits insulin production in $\beta$ cells [71]. In $\beta$-cell-specific leptin receptor knockout mice, this inhibition was abolished, and hyperinsulinemia was observed [70]. The 
mice first exhibited hyperinsulinemia, and then developed insulin resistance [70]. The study provides an excellent answer to the hyperinsulinemia in leptin resistant mouse models, such as $o b / o b$ mice (leptin deficient) and $d b / d b$ mice (leptin receptor deficient). Other evidence in this line includes that mice with extra copies of the insulin gene had two to four-fold of insulin elevation in blood [68]. The mice were normal in weight but with insulin resistance, hyperglycemia, and hypertriglyceridemia. In rats and humans, escalating doses of insulin induced both hyperinsulinemia and insulin resistance [68]. In contrast, reduction of insulin production in $\beta$ cells by decreasing insulin gene dose prevented insulin resistance in mice on high fat diet in a recent study [72]. Those studies consistently support that over production or supply of insulin leads to hyperinsulinemia, and causes insulin resistance in human and animal models. The mechanism is inhibition of IRS-1/2 function after activation of the negative feedback loop in the insulin signaling pathway [1].

Insulin clearance occurs in liver and kidney [73]. Both organs produce glucose as well in the control of blood glucose. Insulin life is about $2-4 \mathrm{~min}$ in the blood. In the process of insulin clearance, insulin is bound to its cell membrane receptor and degraded by insulin degrading enzyme in the cytosol after internalization [73]. In this way, liver and kidney each remove $50 \%$ of insulin in the blood stream. The clearance is dependent on the insulin receptor and insulin degrading enzyme. When these two molecules are deficient from gene inactivation in mice, insulin clearance will be blocked leading to hyperinsulinemia [74-76]. In those mice, insulin resistance and type 2 diabetes were reported, and the mechanism was attributed to the hyperinsulinemia. Those studies strongly suggest that impairment of insulin clearance may cause insulin resistance as a consequence of hyperinsulinemia.

Production of glucose is a major function of the liver in the maintenance of homeostasis of blood glucose in the fasting condition. A failure in this function contributes to hypoglycemia. Glucose production by the liver is inhibited by insulin in fed condition. When the liver develops insulin resistance, the liver will keep producing glucose in both fed and fasting conditions leading to hyperglycemia. Liver function is important in the control of homeostasis of blood glucose.

\section{Other risk factors for insulin resistance}

\section{Aging}

Insulin resistance has a high prevalence in aging people. This is related to increased prevalence of central obesity in aging population. Imbalance of sex hormone and lack of physical exercise contribute to the central obesity in aging people. Removal of visceral fat is able to prevent insulin resistance in aging [77]. Other factors that increase risk of insulin resistance in aging include free radical that leads to oxidative stress in aging, and mitochondrial dysfunction $[54,78,79]$. Oxidative stress and mitochondrial dysfunction have been used to explain insulin resistance in aging $[54,78,80]$. However, those hypotheses remain to be proved. A new hypothesis may be required. In this regard, the energy-centered hypothesis is promising. In aging, energy (ATP) demand is reduced from less physical and mental activities. This leads to relative energy surplus. ATP may induce insulin resistance by inhibiting the AMPK pathway.

\section{Genetic background}

Insulin resistance is determined by multiple factors. However, the gene background is a key factor. This is supported by several lines of evidence. The first is that insulin resistance patients are often associated with family history of type 2 diabetes. The second is high risk of insulin resistance in certain ethnic population in epidemiology study. In US, black Americans and Pima Indians have a higher risk of insulin resistance than Caucasians 
Americans. In Asian countries, Indian and Chinese are also at high risk of insulin resistance. Although central obesity, mitochondrial dysfunction, hypoadiponectinemia and inflammation may contribute to the high risk of insulin resistance, increased ATP production in muscle may be a new mechanism. This possibility is supported by the association of high ATP production and high susceptibility to insulin resistance in the Asian Indians [81].

\section{Lipotoxicity}

Free fatty acid (FFA, also called non-esterified fatty acid) is a risk factor of insulin resistance [82-84]. Plasma FFA is usually increased in fasting condition and decreased after meal in the physiological condition. The plasma level of FFA is tightly controlled by insulin. When FFAs is persistently maintained at a high level, it leads to systemic insulin resistance and type 2 diabetes. This condition is often observed in patients with a high risk of type 2 diabetes [85]. Lipodystrophy and adipose tissue dysfunction contribute to the FFA elevation [86,87]. In healthy people, FFA elevation from lipid infusion induces insulin resistance in skeletal muscle [63]. In the mechanism, FFAs may suppress IRS-1 through activation of the negative feedback loop of the insulin receptor pathway [1]. Two intermediate metabolites of FFAs (DAG and ceramide) are involved in the inhibition of insulin sensitivity. Reduction of DAG and Ceramide in the skeletal muscle by physical exercise is able to improve insulin sensitivity [88]. I propose that FFAs may act through induction of mitochondrial $\beta$ oxidation, which yields a large amount of ATP and acetyl-CoA. This possibility is supported by that activation of mitochondrial function in $\beta$-oxidation led to insulin resistance, and inhibition of $\beta$-oxidation with pharmacological inhibitors (etomoxir or oxfenicine) prevented insulin resistance in rodents $[57,58]$. Although some studies suggest that activation of $\beta$ oxidation protects insulin sensitivity [89,90], the mechanism might be release of energy in heat that prevents excessive ATP production. If ATP level is elevated in cells, AMPK activity will be inhibited leading to insulin resistance [91]. Activation of AMPK represents a promising approach for improvement of insulin sensitivity [92].

FFA elevation is often associated with hyperlipidemia, which is a risk factor of insulin resistance. Hyperlipidemia includes an increase in cholesterol, FFA, and TG in the plasma. These lipid indicators are normally downregulated by insulin. When insulin resistance happens, one or more of these parameters will increase in the blood. Insulin stimulates uptake of FFA by liver and adipose tissue, and conversion of FFA into TG. Insulin also induce uptake of TG in lipid protein by adipocytes. When adipose tissue lost response to insulin, the levels of FFA and TG will increase in the blood.

FFA was considered to induce insulin resistance through induction of inflammation. FFA, such as palmitate (saturated FFA) and linoleic acids, was reported to induce activation of IKK/NF- $\kappa$ B pathway through an interaction with Toll-like receptor 4 (TLR4) [93-95]. TLR4 is a cell membrane receptor for endotoxin (LPS) in macrophages and adipocytes. Alternatively, FFA was proposed to induce inflammation after conversion into DAG or ceramide, which are intracellular signaling molecules [96,97]. DAG is an endogenous activator for PKC (protein kinase C), which activates IKKs and JNKs. DAG is generated as an intermediate product in cells during triglyceride biosynthesis. However, a consensus about relative significance of this inflammatory pathway remains to be established in vivo for FFA. The major challenge is the disassociation of FFA level with inflammation in the fasting condition, where plasma FFA is high and inflammation is low. In addition, inflammation is observed without FFA elevation in plasma in diet-induced obese mice.

\section{Endoplasmic reticulum stress}

Endoplasmic reticulum (ER) stress was first found to induce chronic inflammation in obesity by activating JNK [98]. It was then reported as a risk factor of insulin resistance [99] 
and leptin resistance in obesity [100]. ER is a membranous network that functions in the synthesis and processing of secretory and membrane proteins. Accumulation of unfolded or misfolded proteins is a major cause of ER stress [101]. ER stress is also called the unfolded protein response (UPR). ER stress is induced by many factors that inhibit protein folding, such as glucose or nutrient deprivation, viral infections, hypoxia, and lipids [101]. In obesity, ER stress may improve insulin sensitivity in liver by activation of p38 MAP kinase [102]. Inhibition of ER stress by chemical drugs is shown to improve insulin sensitivity in obese mice [103]. Although the ER stress hypothesis is supported by strong evidence in animal models, the relevance of ER stress to human insulin resistance remains unclear.

\section{Hypoxia}

In clinic, obstructive sleep apnoea (OSA, sleep apnea) is associated with insulin resistance in obese subjects [104]. The syndrome of OSA is characterized by recurrent collapse of the upper airway during sleep leading to periods of intermittent hypoxia (IH) and fragmentation of sleep. The prevalence of OSA is $40 \%$ to $60 \%$ in obese subjects. OSA increases risk of insulin resistance, hypertension, coronary artery disease and stroke. Systemic hypoxia was proposed as a risk factor for insulin resistance in patients with sleep apnea. This line of evidence suggests the role of hypoxia in the pathogenesis of insulin resistance. In a recent study, acute systemic hypoxia was shown to induce insulin resistance in lean mice [105]. The insulin resistance was examined with insulin clamp techniques. The result suggests that hypoxia may not act through liver for insulin resistance since hepatic glucose output was not changed by hypoxia in mice. The study excludes the role of autonomic nervous system (ANS) in the hypoxia-induced insulin resistance in OSA. Our study suggests that local hypoxia may contribute to the inflammatory response in adipose tissue [106].

\section{Oxidative stress}

Oxidative stress is a result of misbalance between production and disposal of reactive oxygen species (ROS). ROS is mainly generated in mitochondria during oxidation of fatty acid or glucose for ATP or heat production. ROS is required for normal signal transduction in cells [107]. However, ROS over production will induce oxidative stress. In obesity, oxidative stress occurs from oversupply of fatty acid and glucose to mitochondria since obesity is often associated with hyperlipidemia and hyperglycemia. In cells, oxidative stress is induced by fatty acid such as oleic acid [108-110], and glucose [111-113]. Hypoxia also induces ROS [114,115]. Under hyperglycemia, advanced glycation end products (AGE) or lipoxidation end products are oxidants in vivo [116].

Oxidative stress has been proposed to play a role in insulin resistance in aging and in type 1 patients with uncontrolled hyperglycemia $[112,117]$. ROS has been reported to inhibit insulin signal transduction by activation of PKC, JNK and NF- $\kappa \mathrm{B}$ [112]. ROS also mediates TNF- $\alpha$ and glucocorticoid signal in insulin resistance [80]. The observation was made in cellular models $[80,118]$. This hypothesis is challenged by the disassociation of ROS and insulin resistance in exercise models, in which muscle contraction generates more ROS and insulin sensitivity is not reduced in exercise. In contrast, insulin sensitivity is enhanced by exercise [119]. Autophagy was reported to mediate exercise signal to improve insulin sensitivity in muscle [120].

\section{Summary}

Insulin resistance is a target in the treatment of type 2 diabetes. However, the treatment is limited by our knowledge on insulin resistance. Although there have been several hypotheses for the pathogenesis of obesity-associated insulin resistance, none of them has led to development of effective drugs or therapies. Instead, the effective drugs and therapies 
have led to development of this energy-centered view of insulin resistance. Inflammation occurs in obesity and associates with insulin resistance. Anti-inflammatory therapies have been tested in many clinical trials, but the efficacy is poor in the improvement of insulin sensitivity [3]. This result might be due to incomplete understanding of metabolic activities of inflammation. Recently, more data suggest that inflammation has beneficial effects on obesity in addition to its detrimental effects [3]. Mitochondrial dysfunction exists in aging patients with type 2 diabetes. However, recent studies consistently suggest that mitochondrial over activation actually induces insulin resistance, in which ATP blocks AMPK activity (Fig. 1). Similarly, prevention of hyperinsulinemia is able to improve insulin sensitivity. Insulin stimulates ATP production in mitochondrial to inhibit AMPK activity under hyperinsulinemia in obesity. Although oxidative stress, ER stress, fatty liver, hypoxia and lipodystrophy are closely associated with obesity and insulin resistance, they may not directly contribute to insulin resistance. Author believes that ATP surplus is the most relevant risk factor for insulin resistance (Fig. 1). The energy surplus signal is mediated by ATP that induces insulin resistance by inhibiting AMPK signaling pathway. We believe that suppression of ATP production in mitochondrial is a promising approach in the treatment of insulin resistance. This possibility is supported by the fact that most insulin sensitizing medicines are able to inhibit ATP production in mitochondria (Fig. 1) [122]. This conclusion provides a unifying mechanism for insulin resistance in obesity and aging. It also explains insulin sensitivity in response to weight loss, exercise, and caloric restriction where energy surplus is attenuated.

\section{Acknowledgments}

Jianping Ye is supported by the National Institute of Health research projects (DK085495, DK068036).

\section{References}

1. Ye J. Role of insulin in the pathogenesis of free fatty acid-induced insulin resistance in skeletal muscle. Endocr Metab Immune Disord Drug Targets. 2007; 7(1):65-74. [PubMed: 17346204]

2. He Q, Gao Z, Yin J, Zhang J, Yun Z, Ye J. Regulation of HIF-1a activity in adipose tissue by obesity-associated factors: adipogenesis, insulin, and hypoxia. Am J Physiol Endocrinol Metab. 2011; 300(5):E877-E885. [PubMed: 21343542]

3. Ye J, McGuinness OP. Inflammation during obesity is not all bad: Evidence from animal and human studies. Am J Physiol Endocrinol Metab. 2012 Dec 26.10.1152/ajpendo.00266.2012Epub ahead of print

4. Shoelson SE, Lee J, Goldfine AB. Inflammation and insulin resistance. J Clin Invest. 2006; 116(7): 1793-1801. [PubMed: 16823477]

5. Hotamisligil GS, Shargill NS, Spiegelman BM. Adipose expression of tumor necrosis factor-alpha: direct role in obesity-linked insulin resistance. Science. 1993; 259(5091):87-91. [PubMed: 7678183]

6. Kershaw EE, Flier JS. Adipose tissue as an endocrine organ. J Clin Endocrinol Metab. 2004; 89(6): 2548-2556. [PubMed: 15181022]

7. Halberg N, Wernstedt-Asterholm I, Scherer PE. The adipocyte as an endocrine cell. Endocrinol Metab Clin North Am. 2008; 37(3):753-768. x-xi. [PubMed: 18775362]

8. Yuan M, Konstantopoulos N, Lee J, Hansen L, Li ZW, Karin M, Shoelson SE. Reversal of obesityand diet-induced insulin resistance with salicylates or targeted disruption of Ikkbeta. Science. 2001; 293(5535):1673-1677. [PubMed: 11533494]

9. Hirosumi J, Tuncman G, Chang L, Görgün CZ, Uysal KT, Maeda K, Karin M, Hotamisligil GS. A central role for JNK in obesity and insulin resistance. Nature. 2002; 420(6913):333-336. [PubMed: 12447443]

10. Ye J. Emerging role of adipose tissue hypoxia in obesity and insulin resistance. Int J Obes (Lond). 2009; 33(1):54-66. [PubMed: 19050672] 
11. Peraldi P, Hotamisligil GS, Buurman WA, White MF, Spiegelman BM. Tumor necrosis factor (TNF)-a inhibits insulin signaling through stimulation of the p55 TNF receptor and activation of sphingomyelinase. J Biol Chem. 1996; 271(22):13018-13022. [PubMed: 8662983]

12. Gao Z, Hwang D, Bataille F, Lefevre M, York D, Quon MJ, Ye J. Serine phosphorylation of insulin receptor substrate 1 by inhibitor kappa B kinase complex. J Biol Chem. 2002; 277(50): 48115-48121. [PubMed: 12351658]

13. Aguirre V, Uchida T, Yenush L, Davis R, White MF. The c-Jun NH(2)-terminal kinase promotes insulin resistance during association with insulin receptor substrate-1 and phosphorylation of Ser (307). J Biol Chem. 2000; 275(12):9047-9054. [PubMed: 10722755]

14. Gao Z, He Q, Peng B, Chiao PJ, Ye J. Regulation of nuclear translocation of HDAC3 by IkBa is required for tumor necrosis factor inhibition of peroxisome proliferator-activated receptor gamma function. J Biol Chem. 2006; 281(7):4540-4547. [PubMed: 16371367]

15. Ye J. Regulation of PPAR $\gamma$ function by TNF-a. Biochem Biophys Res Commun. 2008; 374(3): 405-408. [PubMed: 18655773]

16. Karin M, Ben-Neriah Y. Phosphorylation meets ubiquitination: the control of NF- $\kappa \mathrm{B}$ activity. Annu Rev Immunol. 2000; 18(1):621-663. [PubMed: 10837071]

17. Zhang J, Gao Z, Yin J, Quon MJ, Ye J. S6K directly phosphorylates IRS-1 on Ser-270 to promote insulin resistance in response to TNF-(a) signaling through IKK2. J Biol Chem. 2008; 283(51): 35375-35382. [PubMed: 18952604]

18. Rui L, Aguirre V, Kim JK, Shulman GI, Lee A, Corbould A, Dunaif A, White MF. Insulin/IGF-1 and TNF-a stimulate phosphorylation of IRS-1 at inhibitory Ser307 via distinct pathways. J Clin Invest. 2001; 107(2):181-189. [PubMed: 11160134]

19. White MF. IRS proteins and the common path to diabetes. Am J Physiol Endocrinol Metab. 2002; 283(3):E413-E422. [PubMed: 12169433]

20. Ye J, Gimble JM. Regulation of stem cell differentiation in adipose tissue by chronic inflammation. Clin Exp Pharmacol Physiol. 2011; 38(12):872-878. [PubMed: 21883381]

21. Xing H, Northrop JP, Grove JR, Kilpatrick KE, Su JL, Ringold GM. TNF a-mediated inhibition and reversal of adipocyte differentiation is accompanied by suppressed expression of PPAR $\gamma$ without effects on Pref-1 expression. Endocrinology. 1997; 138(7):2776-2783. [PubMed: 9202217]

22. Ruan H, Hacohen N, Golub TR, Van Parijs L, Lodish HF. Tumor necrosis factor-a suppresses adipocyte-specific genes and activates expression of preadipocyte genes in 3T3-L1 adipocytes: nuclear factor-kappaB activation by TNF-a is obligatory. Diabetes. 2002; 51(5):1319-1336. [PubMed: 11978627]

23. Suzawa M, Takada I, Yanagisawa J, Ohtake F, Ogawa S, Yamauchi T, Kadowaki T, Takeuchi Y, Shibuya H, Gotoh Y, Matsumoto K, Kato S. Cytokines suppress adipogenesis and PPAR- $\gamma$ function through the TAK1/TAB1/NIK cascade. Nat Cell Biol. 2003; 5(3):224-230. [PubMed: 12598905]

24. Anforth HR, Bluthe RM, Bristow A, Hopkins S, Lenczowski MJ, Luheshi G, Lundkvist J, Michaud B, Mistry Y, Van Dam AM, Zhen C, Dantzer R, Poole S, Rothwell NJ, Tilders FJ, Wollman EE. Biological activity and brain actions of recombinant rat interleukin-1a and interleukin-1 $\beta$. Eur Cytokine Netw. 1998; 9(3):279-288. [PubMed: 9831177]

25. García MC, Wernstedt I, Berndtsson A, Enge M, Bell M, Hultgren O, Horn M, Ahrén B, Enerback $\mathrm{S}$, Ohlsson C, Wallenius V, Jansson JO. Mature-onset obesity in interleukin-1 receptor I knockout mice. Diabetes. 2006; 55(5):1205-1213. [PubMed: 16644674]

26. Wallenius V, Wallenius K, Ahrén B, Rudling M, Carlsten H, Dickson SL, Ohlsson C, Jansson JO. Interleukin-6-deficient mice develop mature-onset obesity. Nat Med. 2002; 8(1):75-79. [PubMed: $11786910]$

27. Xu H, Hirosumi J, Uysal KT, Guler AD, Hotamisligil GS. Exclusive action of transmembrane $\mathrm{TNFa}$ in adipose tissue leads to reduced adipose mass and local but not systemic insulin resistance. Endocrinology. 2002; 143(4):1502-1511. [PubMed: 11897709]

28. Pamir N, McMillen TS, Kaiyala KJ, Schwartz MW, LeBoeuf RC. Receptors for tumor necrosis factor-a play a protective role against obesity and alter adipose tissue macrophage status. Endocrinology. 2009; 150(9):4124-4134. [PubMed: 19477937] 
29. Chida D, Osaka T, Hashimoto O, Iwakura Y. Combined interleukin-6 and interleukin-1 deficiency causes obesity in young mice. Diabetes. 2006; 55(4):971-977. [PubMed: 16567518]

30. Xu H, Barnes GT, Yang Q, Tan G, Yang D, Chou CJ, Sole J, Nichols A, Ross JS, Tartaglia LA, Chen H. Chronic inflammation in fat plays a crucial role in the development of obesity-related insulin resistance. J Clin Invest. 2003; 112(12):1821-1830. [PubMed: 14679177]

31. Weisberg SP, McCann D, Desai M, Rosenbaum M, Leibel RL, Ferrante AW Jr. Obesity is associated with macrophage accumulation in adipose tissue. J Clin Invest. 2003; 112(12):17961808. [PubMed: 14679176]

32. Di Gregorio GB, Yao-Borengasser A, Rasouli N, Varma V, Lu T, Miles LM, Ranganathan G, Peterson CA, McGehee RE, Kern PA. Expression of CD68 and macrophage chemoattractant protein-1 genes in human adipose and muscle tissues: association with cytokine expression, insulin resistance, and reduction by pioglitazone. Diabetes. 2005; 54(8):2305-2313. [PubMed: 16046295]

33. Fain JN. Release of interleukins and other inflammatory cytokines by human adipose tissue is enhanced in obesity and primarily due to the nonfat cells. Vitam Horm. 2006; 74:443-477. [PubMed: 17027526]

34. Odegaard JI, Ricardo-Gonzalez RR, Goforth MH, Morel CR, Subramanian V, Mukundan L, Red Eagle A, Vats D, Brombacher F, Ferrante AW, Chawla A. Macrophage-specific PPAR $\gamma$ controls alternative activation and improves insulin resistance. Nature. 2007; 447(7148):1116-1120. [PubMed: 17515919]

35. Hevener AL, Olefsky JM, Reichart D, Nguyen MTA, Bandyopadyhay G, Leung HY, Watt MJ, Benner C, Febbraio MA, Nguyen AK, Folian B, Subramaniam S, Gonzalez FJ, Glass CK, Ricote M. Macrophage PPAR $\gamma$ is required for normal skeletal muscle and hepatic insulin sensitivity and full antidiabetic effects of thiazolidinediones. J Clin Invest. 2007; 117(6):1658-1669. [PubMed: 17525798]

36. Lumeng CN, Bodzin JL, Saltiel AR. Obesity induces a phenotypic switch in adipose tissue macrophage polarization. J Clin Invest. 2007; 117(1):175-184. [PubMed: 17200717]

37. Gordon S. Alternative activation of macrophages. Nat Rev Immunol. 2003; 3(1):23-35. [PubMed: 12511873]

38. Mosser DM. The many faces of macrophage activation. J Leukoc Biol. 2003; 73(2):209-212. [PubMed: 12554797]

39. Nishimura S, Manabe I, Nagasaki M, Hosoya Y, Yamashita H, Fujita H, Ohsugi M, Tobe K, Kadowaki T, Nagai R, Sugiura S. Adipogenesis in obesity requires close interplay between differentiating adipocytes, stromal cells, and blood vessels. Diabetes. 2007; 56(6):1517-1526. [PubMed: 17389330]

40. Cho CH, Koh YJ, Han J, Sung HK, Jong Lee H, Morisada T, Schwendener RA, Brekken RA, Kang G, Oike Y, Choi TS, Suda T, Yoo OJ, Koh GY. Angiogenic role of LYVE-1-positive macrophages in adipose tissue. Circ Res. 2007; 100(4):e47-e57. [PubMed: 17272806]

41. Lijnen HR. Angiogenesis and obesity. Cardiovasc Res. 2008; 78(2):286-293. [PubMed: 18006485]

42. Pang C, Gao Z, Yin J, Zhang J, Jia W, Ye J. Macrophage infiltration into adipose tissue may promote angiogenesis for adipose tissue remodeling in obesity. Am J Physiol Endocrinol Metab. 2008; 295(2):E313-E322. [PubMed: 18492768]

43. Cinti S, Mitchell G, Barbatelli G, Murano I, Ceresi E, Faloia E, Wang S, Fortier M, Greenberg AS, Obin MS. Adipocyte death defines macrophage localization and function in adipose tissue of obese mice and humans. J Lipid Res. 2005; 46(11):2347-2355. [PubMed: 16150820]

44. Clavien PA. IL-6, a key cytokine in liver regeneration. Hepatology. 1997; 25(5):1294-1296. [PubMed: 9141458]

45. Cai D, Yuan M, Frantz DF, Melendez PA, Hansen L, Lee J, Shoelson SE. Local and systemic insulin resistance resulting from hepatic activation of IKK-beta and NF- $\kappa B$. Nat Med. 2005; 11(2): 183-190. [PubMed: 15685173]

46. Arkan MC, Hevener AL, Greten FR, Maeda S, Li ZW, Long JM, Wynshaw-Boris A, Poli G, Olefsky J, Karin M. IKK- $\beta$ links inflammation to obesity-induced insulin resistance. Nat Med. 2005; 11(2):191-198. [PubMed: 15685170]

47. Tang T, Zhang J, Yin J, Staszkiewicz J, Gawronska-Kozak B, Jung DY, Ko HJ, Ong H, Kim JK, Mynatt R, Martin RJ, Keenan M, Gao Z, Ye J. Uncoupling of inflammation and insulin resistance 
by NF- $\kappa \mathrm{B}$ in transgenic mice through elevated energy expenditure. J Biol Chem. 2010; 285(7): 4637-4644. [PubMed: 20018865]

48. Jiao P, Feng B, Ma J, Nie Y, Paul E, Li Y, Xu H. Constitutive activation of IKK $\beta$ in adipose tissue prevents diet-induced obesity in mice. Endocrinology. 2012; 153(1):154-165. [PubMed: 22067324]

49. Pedersen BK. IL-6 signalling in exercise and disease. Biochem Soc Trans. 2007; 35(5):1295-1297. [PubMed: 17956334]

50. Fearon KC, Glass DJ, Guttridge DC. Cancer cachexia: mediators, signaling, and metabolic pathways. Cell Metab. 2012; 16(2):153-166. [PubMed: 22795476]

51. Straub RH, Cutolo M, Buttgereit F, Pongratz G. Energy regulation and neuroendocrine-immune control in chronic inflammatory diseases. J Intern Med. 2010; 267(6):543-560. [PubMed: 20210843]

52. Ye J, Keller JN. Regulation of energy metabolism by inflammation: a feedback response in obesity and calorie restriction. Aging (Albany NY). 2010; 2(6):361-368. [PubMed: 20606248]

53. Holloszy JO. Exercise-induced increase in muscle insulin sensitivity. J Appl Physiol. 2005; 99(1): 338-343. [PubMed: 16036907]

54. Lowell BB, Shulman GI. Mitochondrial dysfunction and type 2 diabetes. Science. 2005; 307(5708):384-387. [PubMed: 15662004]

55. Szendroedi J, Phielix E, Roden M. The role of mitochondria in insulin resistance and type 2 diabetes mellitus. Nat Rev Endocrinol. 2012; 8(2):92-103. [PubMed: 21912398]

56. Holloszy JO. Skeletal muscle "mitochondrial deficiency" does not mediate insulin resistance. Am J Clin Nutr. 2009; 89(1):463S-466S. [PubMed: 19056574]

57. Pagel-Langenickel I, Bao J, Pang L, Sack MN. The role of mitochondria in the pathophysiology of skeletal muscle insulin resistance. Endocr Rev. 2010; 31(1):25-51. [PubMed: 19861693]

58. Muoio DM. Intramuscular triacylglycerol and insulin resistance: guilty as charged or wrongly accused? Biochim Biophys Acta. 2010; 1801(3):281-288. [PubMed: 19958841]

59. Morino K, Petersen KF, Dufour S, Befroy D, Frattini J, Shatzkes N, Neschen S, White MF, Bilz S, Sono S, Pypaert M, Shulman GI. Reduced mitochondrial density and increased IRS-1 serine phosphorylation in muscle of insulin-resistant offspring of type 2 diabetic parents. J Clin Invest. 2005; 115(12):3587-3593. [PubMed: 16284649]

60. Stump CS, Short KR, Bigelow ML, Schimke JM, Nair KS. Effect of insulin on human skeletal muscle mitochondrial ATP production, protein synthesis, and mRNA transcripts. Proc Natl Acad Sci USA. 2003; 100(13):7996-8001. [PubMed: 12808136]

61. Sreekumar R, Halvatsiotis P, Schimke JC, Nair KS. Gene expression profile in skeletal muscle of type 2 diabetes and the effect of insulin treatment. Diabetes. 2002; 51(6):1913-1920. [PubMed: 12031981]

62. Boden G, Jadali F, White J, Liang Y, Mozzoli M, Chen X, Coleman E, Smith C. Effects of fat on insulin-stimulated carbohydrate metabolism in normal men. J Clin Invest. 1991; 88 (3):960-966. [PubMed: 1885781]

63. Roden M, Price TB, Perseghin G, Petersen KF, Rothman DL, Cline GW, Shulman GI. Mechanism of free fatty acid-induced insulin resistance in humans. J Clin Invest. 1996; 97(12):2859-2865. [PubMed: 8675698]

64. Brunmair B, Staniek K, Gras F, Scharf N, Althaym A, Clara R, Roden M, Gnaiger E, Nohl H, Waldhäusl W, Fürnsinn C. Thiazolidinediones, like metformin, inhibit respiratory complex I: a common mechanism contributing to their antidiabetic actions? Diabetes. 2004; 53(4):1052-1059. [PubMed: 15047621]

65. Owen MR, Doran E, Halestrap AP. Evidence that metformin exerts its anti-diabetic effects through inhibition of complex 1 of the mitochondrial respiratory chain. Biochem J. 2000; 348(3):607-614. [PubMed: 10839993]

66. Yin J, Gao Z, Liu D, Liu Z, Ye J. Berberine improves glucose metabolism through induction of glycolysis. Am J Physiol Endocrinol Metab. 2008; 294(1):E148-E156. [PubMed: 17971514]

67. Hawley SA, Ross FA, Chevtzoff C, Green KA, Evans A, Fogarty S, Towler MC, Brown LJ, Ogunbayo OA, Evans AM, Hardie DG. Use of cells expressing gamma subunit variants to identify diverse mechanisms of AMPK activation. Cell Metab. 2010; 11(6):554-565. [PubMed: 20519126] 
68. Shanik MH, Xu Y, Skrha J, Dankner R, Zick Y, Roth J. Insulin resistance and hyperinsulinemia: is hyperinsulinemia the cart or the horse? Diabetes Care. 2008; 31(Suppl 2):S262-S268. [PubMed: 18227495]

69. Corkey BE. Banting lecture 2011: hyperinsulinemia: cause or consequence? Diabetes. 2012; 61(1): 4-13. [PubMed: 22187369]

70. Gray SL, Donald C, Jetha A, Covey SD, Kieffer TJ. Hyperinsulinemia precedes insulin resistance in mice lacking pancreatic $\beta$-cell leptin signaling. Endocrinology. 2010; 151(9):4178-4186. [PubMed: 20631001]

71. Zhao AZ, Bornfeldt KE, Beavo JA. Leptin inhibits insulin secretion by activation of phosphodiesterase 3B. J Clin Invest. 1998; 102(5):869-873. [PubMed: 9727054]

72. Mehran AE, Templeman NM, Brigidi GS, Lim GE, Chu KY, Hu X, Botezelli JD, Asadi A, Hoffman BG, Kieffer TJ, Bamji SX, Clee SM, Johnson JD. Hyperinsulinemia drives diet-induced obesity independently of brain insulin production. Cell Metab. 2012; 16(6):723-737. [PubMed: 23217255]

73. Valera Mora ME, Scarfone A, Calvani M, Greco AV, Mingrone G. Insulin clearance in obesity. J Am Coll Nutr. 2003; 22(6):487-493. [PubMed: 14684753]

74. Michael MD, Kulkarni RN, Postic C, Previs SF, Shulman GI, Magnuson MA, Kahn CR. Loss of insulin signaling in hepatocytes leads to severe insulin resistance and progressive hepatic dysfunction. Mol Cell. 2000; 6(1):87-97. [PubMed: 10949030]

75. Farris W, Mansourian S, Chang Y, Lindsley L, Eckman EA, Frosch MP, Eckman CB, Tanzi RE, Selkoe DJ, Guenette S. Insulin-degrading enzyme regulates the levels of insulin, amyloid $\beta$ protein, and the $\beta$-amyloid precursor protein intracellular domain in vivo. Proc Natl Acad Sci USA. 2003; 100(7):4162-4167. [PubMed: 12634421]

76. Farris W, Mansourian S, Leissring MA, Eckman EA, Bertram L, Eckman CB, Tanzi RE, Selkoe DJ. Partial loss-of-function mutations in insulin-degrading enzyme that induce diabetes also impair degradation of amyloid $\beta$-protein. Am J Pathol. 2004; 164 (4):1425-1434. [PubMed: 15039230]

77. Gabriely I, Ma XH, Yang XM, Atzmon G, Rajala MW, Berg AH, Scherer P, Rossetti L, Barzilai N. Removal of visceral fat prevents insulin resistance and glucose intolerance of aging: an adipokine-mediated process? Diabetes. 2002; 51(10):2951-2958. [PubMed: 12351432]

78. Petersen KF, Befroy D, Dufour S, Dziura J, Ariyan C, Rothman DL, DiPietro L, Cline GW, Shulman GI. Mitochondrial dysfunction in the elderly: possible role in insulin resistance. Science. 2003; 300(5622):1140-1142. [PubMed: 12750520]

79. Reznick RM, Zong H, Li J, Morino K, Moore IK, Yu HJ, Liu ZX, Dong J, Mustard KJ, Hawley SA, Befroy D, Pypaert M, Hardie DG, Young LH, Shulman GI. Aging-associated reductions in AMP-activated protein kinase activity and mitochondrial biogenesis. Cell Metab. 2007; 5(2):151156. [PubMed: 17276357]

80. Houstis N, Rosen ED, Lander ES. Reactive oxygen species have a causal role in multiple forms of insulin resistance. Nature. 2006; 440(7086):944-948. [PubMed: 16612386]

81. Nair KS, Bigelow ML, Asmann YW, Chow LS, Coenen-Schimke JM, Klaus KA, Guo ZK, Sreekumar R, Irving BA. Asian Indians have enhanced skeletal muscle mitochondrial capacity to produce ATP in association with severe insulin resistance. Diabetes. 2008; 57(5):1166-1175. [PubMed: 18285554]

82. Bergman RN, Ader M. Free fatty acids and pathogenesis of type 2 diabetes mellitus. Trends Endocrinol Metab. 2000; 11(9):351-356. [PubMed: 11042464]

83. Shulman GI. Cellular mechanisms of insulin resistance. J Clin Invest. 2000; 106(2):171-176. [PubMed: 10903330]

84. Boden G. Free fatty acids and insulin secretion in humans. Curr Diab Rep. 2005; 5(3):167-170. [PubMed: 15929861]

85. Paolisso G, Tataranni PA, Foley JE, Bogardus C, Howard BV, Ravussin E. A high concentration of fasting plasma non-esterified fatty acids is a risk factor for the development of NIDDM. Diabetologia. 1995; 38(10):1213-1217. [PubMed: 8690174]

86. Heilbronn L, Smith SR, Ravussin E. Failure of fat cell proliferation, mitochondrial function and fat oxidation results in ectopic fat storage, insulin resistance and type II diabetes mellitus. Int J Obes Relat Metab Disord. 2004; 28(Suppl 4):S12-S21. [PubMed: 15592481] 
87. Shimomura I, Hammer RE, Richardson JA, Ikemoto S, Bashmakov Y, Goldstein JL, Brown MS. Insulin resistance and diabetes mellitus in transgenic mice expressing nuclear SREBP-1c in adipose tissue: model for congenital generalized lipodystrophy. Genes Dev. 1998; 12(20):31823194. [PubMed: 9784493]

88. Schenk S, Horowitz JF. Acute exercise increases triglyceride synthesis in skeletal muscle and prevents fatty acid-induced insulin resistance. J Clin Invest. 2007; 117(6):1690-1698. [PubMed: 17510709]

89. Yadav H, Quijano C, Kamaraju AK, Gavrilova O, Malek R, Chen W, Zerfas P, Zhigang D, Wright EC, Stuelten C, Sun P, Lonning S, Skarulis M, Sumner AE, Finkel T, Rane SG. Protection from obesity and diabetes by blockade of TGF- $\beta /$ Smad3 signaling. Cell Metab. 2011; 14(1):67-79. [PubMed: 21723505]

90. Tan CK, Leuenberger N, Tan MJ, Yan YW, Chen Y, Kambadur R, Wahli W, Tan NS. Smad3 deficiency in mice protects against insulin resistance and obesity induced by a high-fat diet. Diabetes. 2011; 60(2):464-476. [PubMed: 21270259]

91. Kahn BB, Alquier T, Carling D, Hardie DG. AMP-activated protein kinase: ancient energy gauge provides clues to modern understanding of metabolism. Cell Metab. 2005; 1(1):15-25. [PubMed: 16054041]

92. Zhang BB, Zhou G, Li C. AMPK: an emerging drug target for diabetes and the metabolic syndrome. Cell Metab. 2009; 9(5):407-416. [PubMed: 19416711]

93. Lee JY, Ye J, Gao Z, Youn HS, Lee WH, Zhao L, Sizemore N, Hwang DH. Reciprocal modulation of Toll-like receptor-4 signaling pathways involving MyD88 and phosphatidylinositol 3-kinase/ AKT by saturated and polyunsaturated fatty acids. J Biol Chem. 2003; 278(39):37041-37051. [PubMed: 12865424]

94. Weigert C, Brodbeck K, Staiger H, Kausch C, Machicao F, Häring HU, Schleicher ED. Palmitate, but not unsaturated fatty acids, induces the expression of interleukin- 6 in human myotubes through proteasome-dependent activation of nuclear factor- $\kappa$ B. J Biol Chem. 2004; 279(23):23942-23952. [PubMed: 15028733]

95. Gao Z, Zhang X, Zuberi A, Hwang D, Quon MJ, Lefevre M, Ye J. Inhibition of insulin sensitivity by free fatty acids requires activation of multiple serine kinases in 3T3-L1 adipocytes. Mol Endocrinol. 2004; 18(8):2024-2034. [PubMed: 15143153]

96. Brose N, Rosenmund C. Move over protein kinase C, you've got company: alternative cellular effectors of diacylglycerol and phorbol esters. J Cell Sci. 2002; 115(23):4399-4411. [PubMed: 12414987]

97. Ballou LR, Laulederkind SJ, Rosloniec EF, Raghow R. Ceramide signalling and the immune response. Biochim Biophys Acta. 1996; 1301(3):273-287. [PubMed: 8664339]

98. Ozcan U, Cao Q, Yilmaz E, Lee AH, Iwakoshi NN, Ozdelen E, Tuncman G, Görgün C, Glimcher LH, Hotamisligil GS. Endoplasmic reticulum stress links obesity, insulin action, and type 2 diabetes. Science. 2004; 306(5695):457-461. [PubMed: 15486293]

99. de Luca C, Olefsky JM. Stressed out about obesity and insulin resistance. Nat Med. 2006; 12(1): 41-42. discussion 42. [PubMed: 16397561]

100. Ozcan L, Ergin AS, Lu A, Chung J, Sarkar S, Nie D, Myers MG Jr, Ozcan U. Endoplasmic reticulum stress plays a central role in development of leptin resistance. Cell Metab. 2009; 9(1): 35-51. [PubMed: 19117545]

101. Schröder M, Kaufman RJ. ER stress and the unfolded protein response. Mutat Res. 2005; 569(12):29-63. [PubMed: 15603751]

102. Lee J, Sun C, Zhou Y, Lee J, Gokalp D, Herrema H, Park SW, Davis RJ, Ozcan U. p38 MAPKmediated regulation of Xbp1s is crucial for glucose homeostasis. Nat Med. 2011; 17(10):12511260. [PubMed: 21892182]

103. Ozcan U, Yilmaz E, Ozcan L, Furuhashi M, Vaillancourt E, Smith RO, Görgün CZ, Hotamisligil GS. Chemical chaperones reduce ER stress and restore glucose homeostasis in a mouse model of type 2 diabetes. Science. 2006; 313(5790):1137-1140. [PubMed: 16931765]

104. Ip MS, Lam B, Ng MM, Lam WK, Tsang KW, Lam KS. Obstructive sleep apnea is independently associated with insulin resistance. Am J Respir Crit Care Med. 2002; 165(5):670676. [PubMed: 11874812] 
105. Iiyori N, Alonso LC, Li J, Sanders MH, Garcia-Ocana A, O’Doherty RM, Polotsky VY, O'Donnell CP. Intermittent hypoxia causes insulin resistance in lean mice independent of autonomic activity. Am J Respir Crit Care Med. 2007; 175(8):851-857. [PubMed: 17272786]

106. Ye J, Gao Z, Yin J, He Q. Hypoxia is a potential risk factor for chronic inflammation and adiponectin reduction in adipose tissue of $o b / o b$ and dietary obese mice. Am J Physiol Endocrinol Metab. 2007; 293(4):E1118-E1128. [PubMed: 17666485]

107. Bashan N, Kovsan J, Kachko I, Ovadia H, Rudich A. Positive and negative regulation of insulin signaling by reactive oxygen and nitrogen species. Physiol Rev. 2009; 89(1):27-71. [PubMed: 19126754]

108. Greene EL, Lu G, Zhang D, Egan BM. Signaling events mediating the additive effects of oleic acid and angiotensin II on vascular smooth muscle cell migration. Hypertension. 2001; 37(2): 308-312. [PubMed: 11230290]

109. Lu G, Greene EL, Nagai T, Egan BM. Reactive oxygen species are critical in the oleic acidmediated mitogenic signaling pathway in vascular smooth muscle cells. Hypertension. 1998; 32(6):1003-1010. [PubMed: 9856964]

110. Furukawa S, Fujita T, Shimabukuro M, Iwaki M, Yamada Y, Nakajima Y, Nakayama O, Makishima M, Matsuda M, Shimomura I. Increased oxidative stress in obesity and its impact on metabolic syndrome. J Clin Invest. 2004; 114(12):1752-1761. [PubMed: 15599400]

111. Lin Y, Berg AH, Iyengar P, Lam TKT, Giacca A, Combs TP, Rajala MW, Du X, Rollman B, Li W, Hawkins M, Barzilai N, Rhodes CJ, Fantus IG, Brownlee M, Scherer PE. The hyperglycemia-induced inflammatory response in adipocytes: the role of reactive oxygen species. J Biol Chem. 2005; 280(6):4617-4626. [PubMed: 15536073]

112. Evans JL, Goldfine ID, Maddux BA, Grodsky GM. Are oxidative stress-activated signaling pathways mediators of insulin resistance and beta-cell dysfunction? Diabetes. 2003; 52(1):1-8. [PubMed: 12502486]

113. Robertson RP. Chronic oxidative stress as a central mechanism for glucose toxicity in pancreatic islet $\beta$ cells in diabetes. J Biol Chem. 2004; 279(41):42351-42354. [PubMed: 15258147]

114. Aragonés J, Fraisl P, Baes M, Carmeliet P. Oxygen sensors at the crossroad of metabolism. Cell Metab. 2009; 9(1):11-22. [PubMed: 19117543]

115. Prabhakar NR, Kumar GK, Nanduri J, Semenza GL. ROS signaling in systemic and cellular responses to chronic intermittent hypoxia. Antioxid Redox Signal. 2007; 9(9):1397-1403. [PubMed: 17627465]

116. Baynes JW, Thorpe SR. Role of oxidative stress in diabetic complications: a new perspective on an old paradigm. Diabetes. 1999; 48(1):1-9. [PubMed: 9892215]

117. Ceriello A. Oxidative stress and glycemic regulation. Metabolism. 2000; 49(2 Suppl 1):27-29. [PubMed: 10693917]

118. Ogihara T, Asano T, Katagiri H, Sakoda H, Anai M, Shojima N, Ono H, Fujishiro M, Kushiyama A, Fukushima Y, Kikuchi M, Noguchi N, Aburatani H, Gotoh Y, Komuro I, Fujita T. Oxidative stress induces insulin resistance by activating the nuclear factor- $\kappa \mathrm{B}$ pathway and disrupting normal subcellular distribution of phosphatidylinositol 3-kinase. Diabetologia. 2004; 47(5):7946805. [PubMed: 15127200]

119. Hu FB, Manson JE, Stampfer MJ, Colditz G, Liu S, Solomon CG, Willett WC. Diet, lifestyle, and the risk of type 2 diabetes mellitus in women. N Engl J Med. 2001; 345(11):790-797. [PubMed: 11556298]

120. He C, Bassik MC, Moresi V, Sun K, Wei Y, Zou Z, An Z, Loh J, Fisher J, Sun Q, Korsmeyer S, Packer M, May HI, Hill JA, Virgin HW, Gilpin C, Xiao G, Bassel-Duby R, Scherer PE, Levine B. Exercise-induced BCL2-regulated autophagy is required for muscle glucose homeostasis. Nature. 2012; 481(7382):511-515. [PubMed: 22258505]

121. Shimomura I, Hammer RE, Ikemoto S, Brown MS, Goldstein JL. Leptin reverses insulin resistance and diabetes mellitus in mice with congenital lipodystrophy. Nature. 1999; 401(6748): 73-76. [PubMed: 10485707]

122. Zhang Y, Ye J. Mitochondrial inhibitor as a new class of insulin sensitizer. Acta Pharmaceutica Sinica B. 2012; 2(4):341-349. [PubMed: 23710432] 


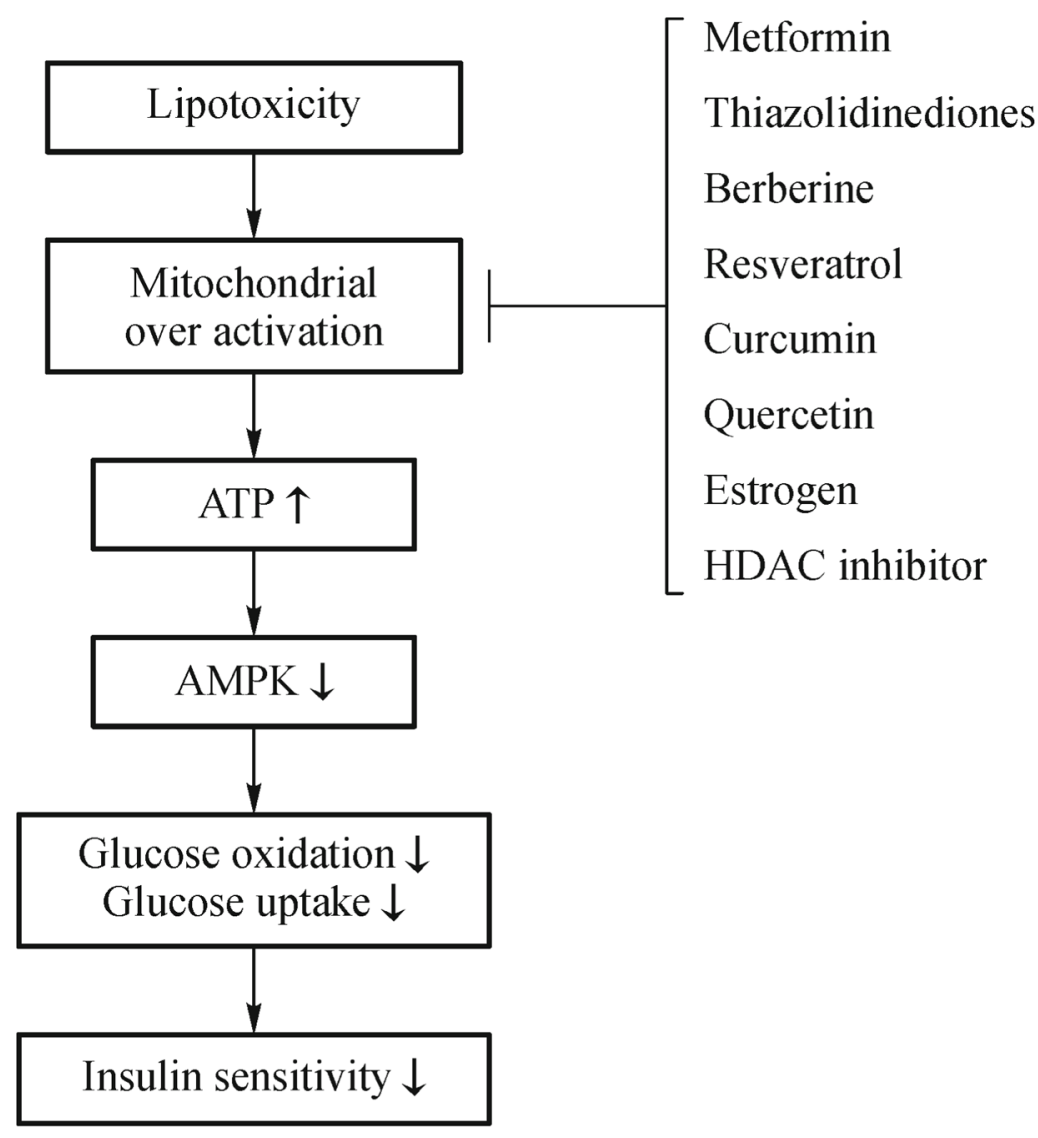

Fig. 1.

Mitochondria over activation in the pathogenesis of insulin resistance. In obesity, lipids induce mitochondrial over activation by boosting fatty acid $\beta$-oxidation to enhance energy disposal especially in muscle, liver and brown fat. As a result, a large amount of ATP is generated from the fatty acid catabolism if the extra energy cannot be released in heat. When ATP level exceeds the threshold, the energy surplus will trigger a negative feedback reaction to attenuate the substrate-induced mitochondrial function. In the mechanism, ATP inactivates AMPK to reduce insulin-induced glucose uptake in order to decrease ATP production. In this model, insulin resistance represents a cellular protective mechanism that is aimed to control the ATP stress response in the muscle and liver. Insulin-sensitizing agents rescue the tissue from insulin resistance by inhibiting mitochondrial $\beta$-oxidation. 


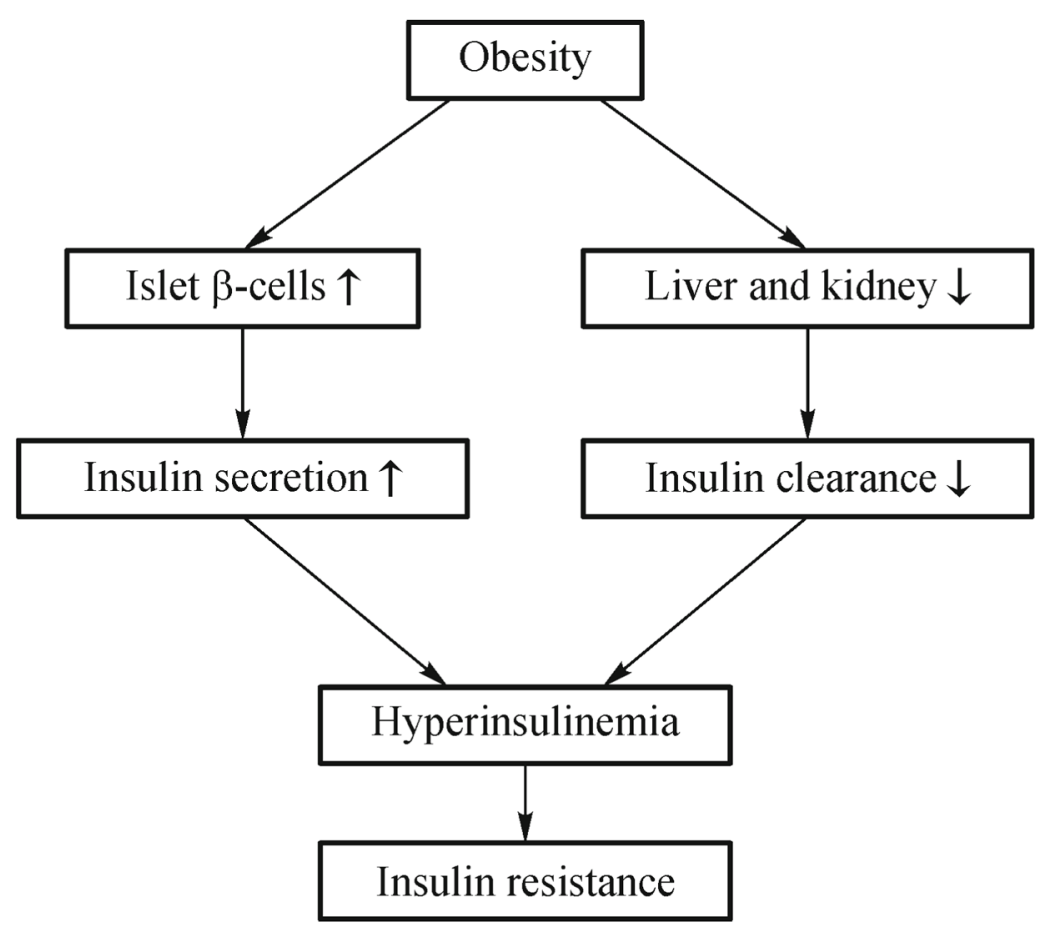

Fig. 2.

Hyperinsulinemia in obesity. 